\title{
Прогностична значущість фізичного та психологічного компонентів здоров'я анкети якості життя SF-36 у дорослих із вродженими вадами серця
}

\author{
Лебідь І. Г. \\ ДУ «Науково-практичний медичний центр дитячої кардіології та кардіохірургії МОЗ України» (Київ)
}

\begin{abstract}
Вивчення якості життя, пов'язаної зі здоров’ям (ЯЖПЗ), дозволяє диференційовано визначити вплив хвороби та їі лікування на психологічний, емоційний стан хворого із вродженими вадами серця (BВC).

Мета роботи - проаналізувати ЯЖПЗ та вивчити прогностичну значущість фізичного та психологічного компонентів здоров’я.

Матеріали та методи. В роботу було включено 456 послідовних хворих із ВВС і 79 здорових дорослих. ЯЖПЗ оцінювалася шляхом використання опитувальника SF-36.

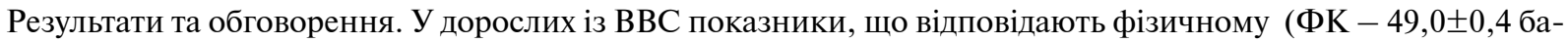
лів) та психічному (ПК - 48,2 $\pm 0,5$ балів) компонентам здоров’я, були гіршими порівняно з контрольною

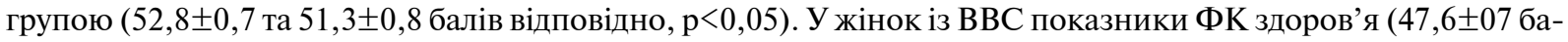
лів) та ПК (46,5 $\pm 0,7$ балів) були знижені порівняно з показниками у групі чоловіків $(50,5 \pm 0,6$ та $49,8 \pm 0,7$ балів, $\mathrm{p}<0,05)$.

Висновки. ВВС у дорослих є неоднорідною нозологічною одиницею, з широким спектром патологічних станів, різним ступенем важкості та різним прогнозом для подальшого життя. Вивчення ЯЖПЗ виявило прогностичну значущість фізичного та психологічного компонентів здоров'я, продемонструвавши погіршення показників зі збільшенням віку хворих. У жінок із ВВС показники обох компонентів здоров'я були достовірно гіршими, що має прогностичну гендерну залежність.
\end{abstract}

Ключові слова: дорослі, серце, вроджені вади, якість життя.

Суб'єктивний характер оцінки стану здоров'я дорослого оперованого або неоперованого хворого із вродженими вадами серця (BВC) повинен бути не тільки підкріплений результатами аналізу симптомів, можливістю виконувати фізичну роботу, настроєм та іншім, а й додатково доповнюватися об'єктивною оцінкою стосовно задоволеності навколишнім середовищем, умовами життя та праці, соціальним забезпеченням, можливістю реалізовувати свої релігійні та особисті потреби [2, 4-6]. Вивчення якості життя, пов'язаної зі здоров'ям (ЯЖПЗ), визначення показників, асоційованих і неасоційованих із захворюванням, має диференційовано визначити вплив хвороби та їі лікування на психологічний, емоційний стан хворого, його соціальний статус у суспільстві, це важливий високоінформативний інструмент у наданні медичної допомоги пацієнтам як із серцево-судинною патологією, так і безпосередньо з уродженими аномаліями серця та магістральних судин $[1,7,8]$.

Мета роботи - проаналізувати ЯЖПЗ і вивчити прогностичну значущість фізичного та психологічного компонентів здоров'я шляхом використання анкети якості життя SF-36 у дорослих із ВBC.
Матеріали та методи. Відповідно до критеріїв відбору всім послідовним пацієнтам, які звернулись у поліклініку ДУ «НПМЦДКК МОЗ України» 301 січня 2014 року по 31 грудня 2015 року, було запропоновано заповнити розроблений нами поєднаний опитувальник, який включав клініко-демографічні питання та коротку форму неспецифічного опитувальника для визначення ЯЖПЗ, - The 36-Item Short Form Health Survey (SF-36). Опитувальник SF-36, який складається із 36 питань, об'єднаних у 8 шкал, заповнювався пацієнтами самостійно. Аналізувалися такі шкали: ФФ - фізичне функціонування; РФоФС - рольове функціонування, зумовлене фізичним станом; ІБ - інтенсивність болю; ЗСЗ - загальний стан здоров'я; ЖА - життєва активність; СФ - соціальне функціонування; РФоЕС - рольове функціонування, обумовлене емоційним станом; П3 - психічне здоров'я) [3, 9]. Представлені шкали дозволяють відокремити фізичні та психологічні особливості ЯЖПЗ: перші чотири показники відповідають за фізичний компонент здоров'я, останні чотири - за психічний.

Критеріями включення до дослідження були: наявність діагнозу ВВС згідно зі стандартизованим визначенням, вік старше 18 років, грамотність, вільне воло- 
діння українською та російською мовами, можливість розуміння поставлених питань, усна інформована згода. За наявності розумової відсталості пацієнти виключалися з дослідження. Статистичний аналіз виконано з використанням пакета програм Statistica 6 (StatSoft Inc., США). Критичний рівень довірчої ймовірності вважався рівним 95\%. Дані відображались у вигляді $\mathrm{M} \pm \mathrm{m}$, де $\mathrm{M}$ - ceреднє арифметичне, $\mathrm{m}$ - похибка середньої величини. Порівняння середніх величин при їх нормальному розподілі проводили за допомогою t-критерію Стьюдента.

Результати та обговорення. Всього було видано 519 протоколів-опитувальників. 63 хворих відмовилися від проведення опитування з різних причин (незгода на збір даних, погане розуміння питань, небажання тощо) або не повернули протоколи для подальшої обробки інформації. В роботу було включено 456 послідовних дорослих із діагнозами ВВС та/або станом після перенесених кардіохірургічних втручань, які становили основну групу. Із них чоловіків було 225 (49,3\%), жінок - 231 (50,7\%). Середній вік склав 27,4 40,5 років (від 18 до 67 років). Переважна кількість пацієнтів $(\mathrm{n}=398)$ на час обстеження була у віці до 40 років (87,3\%), 58 (12,7\%) хворих - старше 40 років.

У досліджуваній групі $321(70,4 \%)$ дорослий мав попередні хірургічні та/або черезшкірні втручання, у 135 $(29,6 \%)$ на час проведення опитування не проводилося жодних кардіологічних або кардіохірургічних втручань. Більшість прооперованих хворих $(\mathrm{n}=218 ; 67,9 \%)$ мали одне втручання з приводу ВВС, 59 (18,3\%) два втручання, 32 (9,9\%) - три, $12(3,7 \%)$ - чотири та більше втручань. У структурі діагнозів переважали дефекти перегородок $(\mathrm{n}=137,30 \%)$, вроджені вади аортального клапана $(\mathrm{n}=89,19 \%)$, коарктація аорти $(\mathrm{n}=46,10 \%)$. Відкрита артеріальна протока, тетрада Фалло, різні формі єдиного шлуночка серця (СШС) та атріовентрикулярного (АВ) каналу, підклапанний і надклапанний аортальний стеноз, частковий і тотальний аномальний дренаж легеневих вен, аномалія Ебштейна становили від 6 до 3\% серед усіх вад серця у дорослих хворих, залучених у дослідження. Тільки 7\% (n=35) пацієнтів мали ознаки гіпоксії із сатурацією менше ніж 90\% та/ або патофізіологію ЄШС та відносилися до великого індексу за даною шкалою важкості.

Порівняльний аналіз отриманих результатів основної та контрольної груп за даними опитувальника по- казав достовірно гірші показники за всіма 8 шкалами в групі дорослих із ВВС (рис. 1).

Важливо зазначити, що максимально можливий бал, що відповідає максимальному значенню, становить 100 балів, однак у контрольній групі здорових дорослих жодні середні показники не досягали 100 балів. Це свідчить про загальне зниження ЯЖПЗ у цілому в практично здорових осіб в країні та, без сумніву, впливає на аналогічні показники у дорослих із вродженими аномаліями серцево-судинної системи (ССС). Більш значущим зниження ЯЖПЗ (середній бал був нижчим за 70 балів) було за показниками, що відповідають загальному стану здоров'я $(59,0 \pm 1,0$ балів), життєвій активності $(69,4 \pm 1,0$ балів) та психічному здоров'ю $(68,6 \pm 0,9$ балів). Два останні показники, що відповідають психічному компоненту здоров'я, були достовірно значно гіршими порівняно з показниками осіб контрольної групи $(71,7 \pm 1,9$ та $74,9 \pm 1,7$ балів відповідно, $\mathrm{p}<0,05)$.

Особливістю опитувальника SF-36 є можливість оцінки сумарних показників, які відповідають окремо фізичному та психічному компонентам здоров'я, що дає узагальнений результат стосовно представлених характеристик ЯЖПЗ. Отримані порівняльні показники основної та контрольної груп представлено на рис. 2.

У дорослих основної групи показники, що відповідають фізичному (49,0 00,4 балів) та психічному $(48,2 \pm 0,5$ балів) компонентам здоров'я, були достовірно гіршими порівняно з аналогічними показниками в контрольній групі $(52,8 \pm 0,7$ та $51,3 \pm 0,8$ балів відповідно, $\mathrm{p}<0,05)$. 


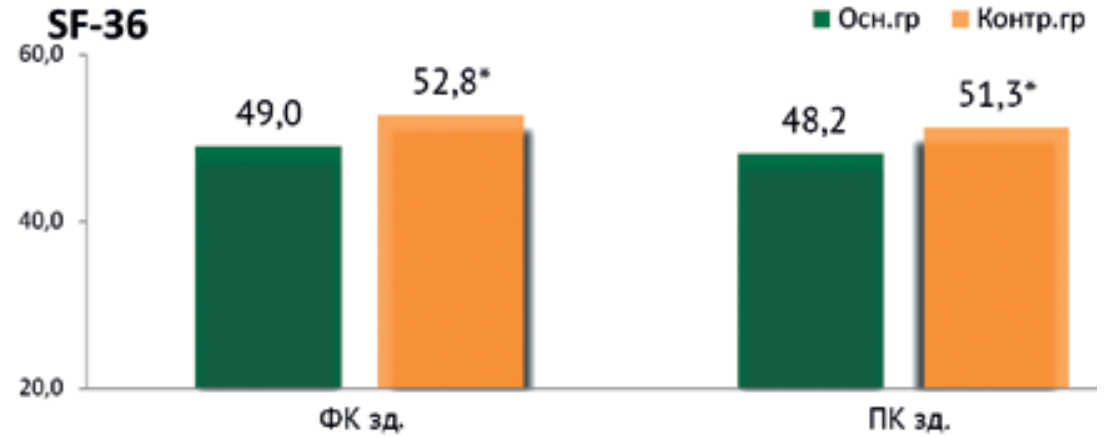

Рис. 2. Порівняльна оцінка результатів підсумкових показників опитувальника SF-36 у досліджуваних групах (* - різниця показників між групами статистично значуща $(p<0,01) ;$ ФКзд - фізичний компонент здоров'я; ПКзд - психічний компонент здоров'я)

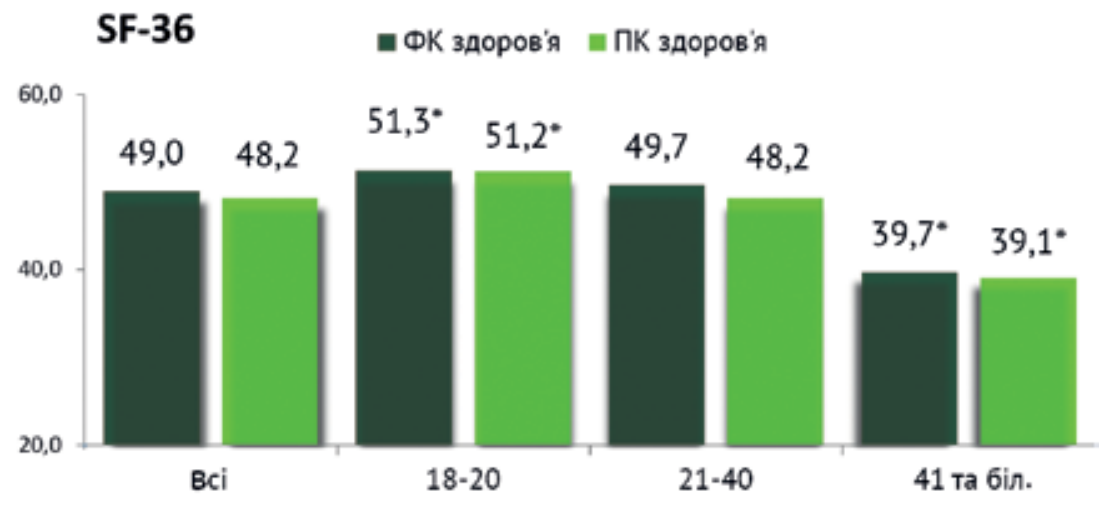

Рис. 3. Порівняльна оцінка результатів підсумкових показників фізичного (ФК) та психічного (ПК) компонентів здоров'я за результатами опитувальника SF-36 залежно від віку пацієнтів основної групи (* - різниця показників між групами статистично значуща $(p<0,01))$

Сумарні показники в цілому в групі дорослих із ВВС не відображають вікової залежності в структурі ЯЖПЗ, тому було проведено роздільне порівняльне оцінювання окремо показників фізичного та психічного здоров'я у досліджуваних групах. Результати і розбіжність залежно від віку наведено на рис. 3 .

Так, показники ФК та ПК здоров'я в молодих дорослих віком від 18 до 20 років були достовірно вищими $(51,3 \pm 0,6$ та $51,2 \pm 0,6$ балів відповідно) порівняно із середніми результатами в основній групі $(49,0 \pm 0,4$ та $48,2 \pm 0,5$ балів відповідно, $\mathrm{p}<0,01)$. Отримані показники не відрізнялися від аналогічних даних у групі практично здорових молодих осіб, що відповідає збереженій ЯЖПЗ у даній віковій групі. Показники дорослих віком 21-40 років відповідали середнім показникам основної групи при відсутності статистично значущої різниці у досліджуваних показниках $(\mathrm{p}>0,05)$. У старших дорослих віком понад 41 рік виявлено достовірно значуше зниження як показника ФК, так і ПК здоров'я $(39,7 \pm 1,2$

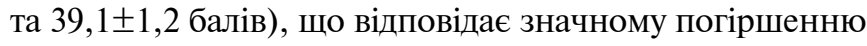

обох компонентів ЯЖПЗ. Такі ознаки потребують не тільки більш ретельної уваги до медичних аспектів у даної когорти пацієнтів, а й вивчення та корекції психосоціальних розладів у старших дорослих із BBC.

Нами були досліджені гендерні особливості ЯЖПЗ у пацієнтів основної групи залежно від віку. Порівняльний аналіз отриманих результатів за основними показниками з використанням опитувальника SF-36 представлено на рис. 4. У жінок основної групи були виявлені достовірно знижені показники, що відповідають обом компонентам здоров'я за даною шкалою (ФК здоров'я - 47,6 $\pm 0,7$ балів, ПК - 46,5 $\pm 0,7$ балів) порівняно 3 аналогічними показниками серед осіб чоловічої статі $(50,5 \pm 0,6$ та 49,8 $\pm 0,7$ балів відповідно, $\mathrm{p}<0,05)$. При аналізі за віком та статтю серед молодих дорослих у віці від 18 до 20 років статистично значущої різниці показників серед чоловіків $(51,7 \pm 08$ та $51,5 \pm 0,9$ балів) та жінок $(50,8 \pm 1,0$ та 50,8 балів, відповідно) в обох компонентах оцінки не виявлено $(\mathrm{p}>0,05)$, а дані відповідали показникам практично здорових осіб контрольної групи. У пацієнтів жіночої статі основної групи віцком від 21 до 40 років виявлено достовірно гірші показники ЯЖПЗ як за фізичним (48,5 $\pm 0,8$ балів), так і за психічним компонентом (46,5 $\pm 1,0$ балів) порівняно з дорослими чоловічої статі відповідного віку $(51,1 \pm 0,8$ та 50,3 $\pm 0,9$ балів відповідно, $\mathrm{p}<0,05)$. Такі зміни свідчать про чітку гендерну залежність серед пацієнтів даної вікової групи.

Аналіз сумарних показників опитувальника SF-36 серед дорослих різної статі віком понад 41 рік виявив чітку тенденцію до більш низьких показників у жінок (ФК - 38,5 $\pm 1,3$ та ПК $-38,3 \pm 1,3$ балів), ніж у чоловіків $(41,6 \pm 2,2$ та 40,5 2,5 балів відповідно), але ця різниця була недостовірною ( $>0,05)$. Ми пов'язуємо це зі значним віковим діапазоном у даній групі (від 41 до 66 років, середній вік становив $53,1 \pm 1,0$ років) та недостатньо великою кількістю включених у дослідження пацієнтів із ВBC $(\mathrm{n}=58)$.

Слід зазначити, що у більш старших дорослих (у нашому дослідженні - понад 41 рік) вік $є$ фактором впливу на показники ЯЖПЗ. Така динаміка пов'язана з наявністю у цих хворих супутньої патології - як кардіологічної (атеросклероз, різні форми IXC, артеріальна гіпертензія, цереброваскулярні захворювання та ін.), так і позасерцевої (захворю- 


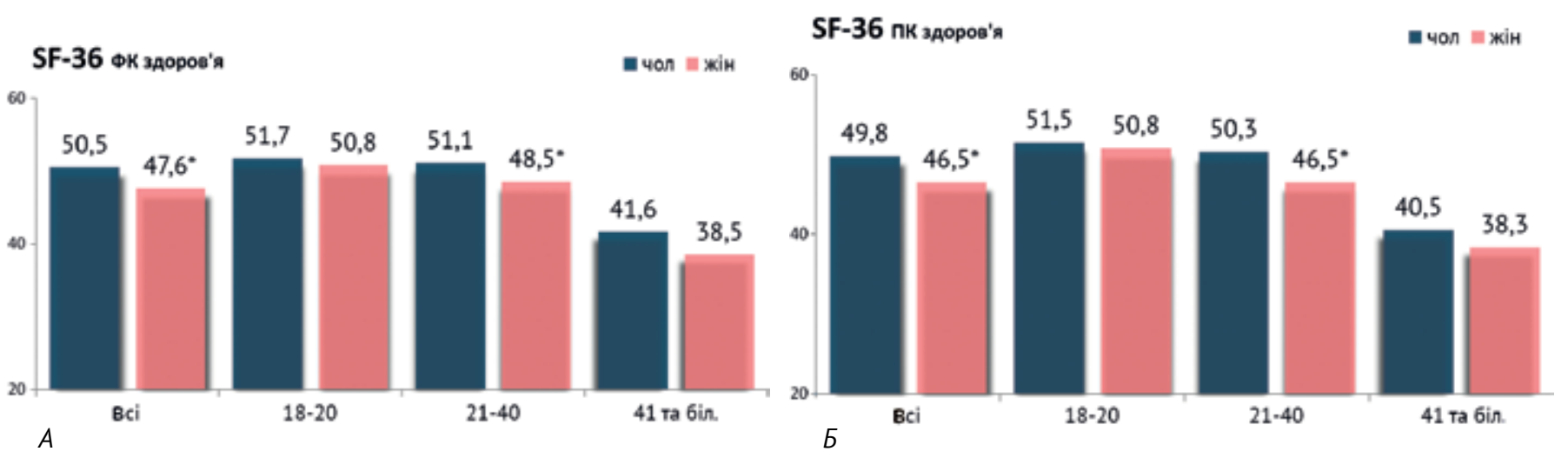

PUс. 4. Порівняльна оцінка фізичного (4A) та психічного (4Б) компонентів здоров'я за результатами опитувальника SF-36 залежно від віку та статі у пацієнтів основної групи (* - різниця показників між групами відповідно до віку статистично значуща $(p<0,05))$

вання дихальної системи, цукровий діабет тощо), зі зменшенням фізичної активності, патологічними звичками (алкоголь, тютюнопаління). Всі ці фактори поряд із віковими змінами знижують ЯЖ і мають бути враховані при наданні кардіологічної допомоги дорослим із ВВС віком понад 41 рік.

Позитивними моментами використання шкали опитувальника SF-36 є окремий аналіз фізичної та психічної складових частин ЯЖПЗ соціального благополуччя, використання узагальнених індексів здоров'я. Однак основними недоліками, на наш погляд, $є$ відносна складність обробки отриманих результатів, а також відсутність запитань, що стосуються сну та сексуального життя, але вони не вплинули на якість отриманих результатів [2].

Висновки. Вроджені вади серця у дорослих є неоднорідною нозологічною одиницею, 3 широким спектром патологічних станів різного ступеня важкості та з різним прогнозом для подальшого життя. Вивчення ЯЖПЗ за даними опитувальника SF-36 показало прогностичну значущість фізичного та психологічного компонентів здоров'я у дорослих із ВВС. Отримані результати серед молодих пацієнтів із ВВС продемонстрували достатньо добрі показники з усіх компонентів здоров'я, в той час як зі збільшенням віку у таких хворих загальні досліджувані показники прогностично погіршилися. У жінок із ВВС показники обох (фізичного та психологічного) компонентів здоров'я за даною шкалою у віці понад 21 рік були достовірно гіршими, що, без сумніву, має прогностичну гендерну залежність і потребує більш ретельної уваги при наданні кардіологічної допомоги таким хворим.

Автор заявляє про відсутність конфлікту інтересів.

\section{Література}

1. Евсина О. В. Качество жизни в медицине - важный показатель состояния здоровья пациента (обзор литературы) // Личность в меняющемся мире: здоровье, адаптация, развитие. - 2013. - № 1. - С. 119-133.

2. Касьянова А. Ю., Лебідь І. Г. Медико-психологічні особливості якості життя молодих дорослих пацієнтів із прооперованими вродженими вадами серця // Журн. клін. та експер. мед. досліджень. - 2014. - Т. 2, вип. 3. - С. 365-372.

3. Лебідь I. Г. Якість життя у пацієнтів із вродженими вадами серця. Практичний посібник / I. Г. Лебідь, Н. М. Руденко, А. Ю. Сидоренко [та ін.]. - Київ : Вид. НПМЦДКК, 2016. - 49 с.

4. Health-related quality of life of patients with pulmonary arterial hypertension associated with CHD: the multicentre cross-sectional ACHILLE study / Amedro P., Basquin A., Gressin V. et al. // Cardiology in the Young. - 2016. Vol. 26 (7). - P. 1250-1259.

5. Quality of Life of Adults With Congenital Heart Disease in 15 Countries: Evaluating Country-Specific Characteristics / Apers S., Kovacs A. H., Luyckx K. et al. // J Am Coll Cardiol. - 2016. - Vol. 67 (19). - P. 2237-2245.

6. Determinants of quality of life in adults with CHD: an Australian cohort / Eaton S. L., Wang Q. F., Menahem S. // Cardiology in the Young. - 2017. - Vol. 27 (8). - P. 1-6.

7. Fteropoulli T. In good heart": a study of the factors associated with health-related quality of life in adult congenital heart disease. - City University London, 2016. - 584 p.

8. Illness perceptions in adult congenital heart disease: A multi-center international study / Rassart J., Apers S., Kovacs A. H. et al. // International Journal of Cardiology. 2017. - Vol. 244. - P. 130-138.

9. Ware J. E. SF-36® Health Survey Update / Ware J. E. // код доступу http://www.sf-36.org/tools/sf36.shtml 


\title{
The predictive significance of physical and mental components of health related quality of life questionnaire SF-36 in adults with congenital heart disease
}

\author{
Lebid I. H. \\ Ukrainian Children's Cardiac Center (Kyiv)
}

Introduction. The estimation of health related quality of life (HRQoL) should determine the impact of the disease and its treatment on the psychological, emotional status adults with congenital heart disease (ACHD).

The purpose was to evaluate HRQoL and estimate the prognostic significance of the physical and mental components of health.

Material and Methods. There were 456 consecutive ACHD that comprised the main group and 79 healthy adults in the control group. HRQoL was evaluated by SF-36 questionnaire.

Results and discussion. Indices of physical health $(\mathrm{PH}-49.0 \pm 0.4)$ and mental health $(\mathrm{MH}-48.2 \pm 0.5)$ in ACHD were worse compared to the control group ( $52,8 \pm 0.7$ and $51.3 \pm 0.8$, respectively, $p<0.05)$. Female with CHD PH $-47.6 \pm 07$ and $\mathrm{MH}-46.5 \pm 0.7$ were lowered compared to men $(50.5 \pm 0.6$ and $49.8 \pm 0.7, \mathrm{p}<0.05)$.

Conclusions. Congenital heart disease in adults are heterogeneous nosology with a wide range of pathology, different level of complexity and prognosis for the follow-up. There were presented prognostic significance the physical and mental components of HRQoL changes, with good indices in young adults, and worse indicators with age increasing. Female with CHD had worse indices of physical and mental components of HRQoL that had a prognostic gender addiction.

Key words: adults, heart, congenital malformations, quality of life.

\section{Прогностическое значение физического и психологического компонентов здоровья анкеты качества жизни SF-36 у взрослых с врожденными пороками сердца}

\author{
Лебедь И. Г.
}

ГУ «Научно-практический медицинский центр детской кардиологии и кардиохирургии МЗ Украины» (Киев)

Изучение качества жизни, связанное со здоровьем (КЖСЗ), позволяет определить влияние болезни и ее лечения на психологическое, эмоциональное состояние больного с врожденными пороками сердца (ВПС).

Цель работы - проанализировать КЖСЗ и изучить прогностическое значение физического и психологического компонентов здоровья.

Материалы и методы. В работу были включены 456 последовательных больных с ВВС и 79 здоровых взрослых. КЖСЗ оценивалось путем использования опросника SF-36.

Результаты и обсуждение. У взрослых с ВВС показатели, соответствующие физическому (ФК - 49,0 0,4 баллов) и психическому (ПК $-48,2 \pm 0,5$ баллов) компонентам здоровья, были хуже по сравнению с контрольной группой $(52,8 \pm 0,7$ и $51,3 \pm 0,8$ баллов соответственно, $\mathrm{p}<0,05)$. У женщин с ВВС показатели ФК здоровья $(47,6 \pm 0,7$

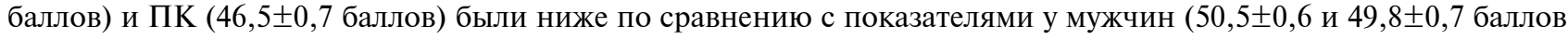
соответственно, $\mathrm{p}<0,05)$.

Выводы. ВВС у взрослых является неоднородной нозологической единицей, с широким спектром патологических состояний, разной степенью тяжести и разным прогнозом для дальнейшей жизни. Изучение ЯЖПЗ выявило прогностическую значимость физического и психологического компонентов здоровья, продемонстрировав ухудшение показателей с увеличением возраста больных. У женщин с ВВС показатели обоих компонентов здоровья были достоверно хуже, что имеет прогностическую гендерную зависимость.

Ключевые слова: взрослые, сердие, врожденные пороки, качество жизни. 